\title{
Courtyard as Tropical Hot Humid Passive Design Strategy: Case Study of Indonesian Contemporary Boarding Houses in Surabaya Indonesia
}

\author{
Agung Murti Nugroho ${ }^{1}$, Andika Citraningrum ${ }^{2}$, Wasiska Iyati $^{3}$, Mohd Hamdan \\ $\mathrm{Ahmad}^{4}$ \\ ${ }_{1,2,3}$ Department of Architecture, Faculty of Engineering, University of Brawijaya Malang, \\ Indonesia \\ ${ }^{4}$ Department of Architecture, Faculty of Built Environment \& Surveying, Universiti Teknologi \\ Malaysia, Skudai, Johor, Malaysia. \\ ${ }^{1}$ sasimurti@yahoo.co.id,agungmurti@ub.ac.id
}

Published: $31^{\text {st }}$ August 2020

\begin{abstract}
Courtyard in building contributes to the indoor thermal environment. Courtyard has a potential aspect of being a micro climate-modifier to reduce indoor air temperature during the day. This paper examines the courtyard's effect on indoor thermal environment in Indonesian contemporary boarding houses using field measurement. This paper focuses on the indoor air temperature reduction of 5 courtyard houses design of the contemporary boarding house in Surabaya, East Java, Indonesia. The field experiment method was used for two physical environmental variables: air temperature and relative humidity. Each sensor was covered with a paper cup wrapped with aluminum foil to protect from direct thermal radiation. Measurement was carried out for 23 days consecutively in each building. The results of the measurement exposed that the form and enclosure element is pivotal in its thermal environment design consideration for tropical climate. Meanwhile, utilizing ventilation blocks as the primary enclosure also helps reduce the air temperature in hot-humid climates. The results indicated that during the daytime, the indoor air temperatures in the courtyard and surrounding room were 0.3 $1.7^{\circ} \mathrm{C}$ below the outdoor air temperature. At nighttime, indoor air temperatures swing to 0.8 $1.9^{\circ} \mathrm{C}$ above the outdoors. The thermal environment evaluation revealed that indoor air temperatures can be categorized as a neutral temperature of the measurement period. Therefore, the use of courtyards in contemporary boarding houses has proven as a feasible means to achieve sufficient cooling effects through a full-day ventilation strategy and showed improved performance when combined with ventilated blocks.
\end{abstract}

Keywords: Inner Courtyard, Temperature Reduction, Contemporary Boarding House

\section{INTRODUCTION}

The energy crisis has become a serious problem in the present and the future so that energy efficiency in all fields, especially buildings are the main concern of research in the field of architecture [1]. The use of new renewable energy in the urban environment continues to be increased along with the escalating of population growth and living standards. One of the most significant contributors to energy consumption per year is the housing sector, and it increases sharply every year, so there is a growing awareness among architects to develop low energy design strategies [2]. This low-energy movement is focused on finding effective passive strategies to reduce building energy consumption, increase energy awareness for users, and provide a comfortable environment. Noble [3] argued that the natural cooling technique worldwide generally depends on the climate condition and its local architectural development. The strategy to lower air temperature levels in the hot-humid climate could be taken through building element utilization, such as the use of the courtyard.

Studies of courtyard over the past five years have been dominated by research in hot-dry climates [4]-[16], followed by hot-humid climates [17][21], and in temperate climates [22]-[25].

The most discussed design elements of courtyard studies in hot-dry regions in sequence are width, orientation, length, height, openings, shade, and water element. Whereas in hot-humid climates, discussion of courtyard elements tends to be evenly distributed, including height, width, length, orientation, sky view factor, and roof shape. In temperate climates, the studies cover 
fewer courtyard elements, including height, width, length, and greenery elements. In general, the courtyard elements studied in each climate are width, length, and height. However, the aspect ratio of the three has not been much discussed.

Courtyard study in hot-dry regions generally use visual methods [6]-[8], [13]-[16], followed the simulation method [4], [5], [9], [11], and measurements [10]. Studies in a hot-humid climate generally use measurement methods [18], [21], and simulations [17], [19], [20]. In a temperate climate, most studies use the simulation method [22], [25], chart [4], and visual method [4]. In general, the widely used methods for courtyard research in all climates are simulation, visuals, measurements, and charts. The combination of various methods has not been done much.

The studies of courtyard performance in hot-dry climate primarily concern about air temperature [9], [12], [14], comfort index [4], [11], [14], air humidity [12], [14], wind speed [12], and energy [13]. In hot-humid climate, most performance studies are concerning the air temperature [17], [18], [20], [21], air humidity [18], [21], wind speed [20], [21], and comfort index [19]. Meanwhile, a study in the temperate climate is focused on air temperature, humidity, wind speed, energy, and comfort index [4]. The widely discussed aspects of courtyard performance are air temperature, air humidity, comfort index, wind speed, and energy.

Sharples and Bensalem [26] conducted a study with wind tunnels and proposed that a courtyard with a porous roof gave a stronger difference in ventilation pressure. Studies show that open courtyard with many openings that operate under negative pressure is the most effective in the urban context. Rajapaksha et al. [27] examined the courtyard's potentials for a natural cooling system in a one-story building located in Colombo, Sri Lanka through field measurement studies and computer simulations. The results show that indoor thermal conditions can be increased through a courtyard which functions as an air chimney that emits hot air indoors through the air stream. This is different courtyard's principle as a wind catcher or suction zone, which is receiving air from outside. Based on the results of field measurements, a strong relationship between the indoor wall's temperature and the temperature inside the room is evident.

Several studies show that the geometry of courtyards affects the received amount of solar radiation and the air temperature inside the building. The square courtyard layout studied by Tablada et al. [28] recommends the importance of cross ventilation and solar radiation protection. Courtyard's geometry is an essential aspect of achieving a good natural ventilation and indoor thermal comfort in a dense urban environment. It is ensured that cross-ventilated rooms have higher indoor air velocity values and hence better thermal comfort than one-sided ventilation. In a one-sided ventilated room, the sun protection factor plays a vital role in maintaining a stable indoor thermal condition even if it is higher than the air temperature at the outside. Muhaisen [29] studied the effect of rectangular courtyard proportions on shade conditions and the resulting exposure on an inner envelope of forms in Kuala Lumpur. Courtyard with small and depth shapes are better than large and wide shapes [29]. The optimal height of the courtyard is found on the third floor in a hot humid climate.

Meanwhile, Dili et al. [30] revealed the results of courtyard measurements in vernacular houses of Kerala, India. Low pressure at the bottom of the courtyard causes the effect of floating ventilation generated by air movement from the outer courtyard through space around the courtyard. Courtyard elements have a unique advantage in hot and humid climates as a passive natural cooling system and provide thermal comfort for users [31]. The result of adding a courtyard roof was able to reduce received solar radiation and improve thermal environmental conditions in adjacent spaces.

The courtyard enclosure wall is an essential element in a microclimate condition, and it could be adjusted to get a positive impact [32]. The research finds a different function of the enclosure wall and its orientation to the thermal performance. Vegetation impact to the courtyard performance carried out by Jamaludin et al. [33]. The average of lower temperature with a relative higher humidity percentage was recorded in a room shaded with a big canopy of trees compared to a room that is exposed to open spaces. A significant correlation is evident between courtyard's sky view factors and air temperature, especially in the daily maximum air temperature and its average value. Reducing the courtyard's sky view factor reduces its air temperature [34]. Kubota [34] shows that cool outdoor air temperatures (about $27-29^{\circ} \mathrm{C}$ ) most likely pass through the building from opening ventilations including exterior walls and upper openings of the courtyards. Meanwhile, a slightly better cooling effect at night achieved by the use of dull day ventilation of courtyard houses even though the exterior windows were closed. 
Zakaria et al. [35] stated that in the hot-humid climates, the form and courtyard orientation were less significant in its environmental design. Thus, the exposure rate of the sky or direct shading should be more or at least equally important determinant of the courtyard's shading effects.

Ghaffarianhoseini [19] evaluated the ability of the courtyard without shading to create a comfortable outdoor space with various designs and scenarios, such as orientation, height, albedo from wall coverings, and the application of vegetation. Increasing the height of courtyard's wall enclosure increases outdoor thermal comfort by reducing intense solar radiation and creating a broader shaded area. Therefore, it could be concluded that design element that affects building courtyard as it is shown to the table below:

Table 1: The Effect of Tropical Courtyard Element to the Natural Building Cooling.

\begin{tabular}{|c|c|c|}
\hline Elements & Criterions & Performance \\
\hline $\begin{array}{l}\text { Courtyard } \\
\text { roof } \\
\text { opening }\end{array}$ & $\begin{array}{l}\text { Courtyard } \\
\text { mono-pitch } \\
\text { roof, large } \\
\text { open space on } \\
\text { the roof's } \\
\text { leeward, } \\
\text { equal to } \\
30,4 \% \text { of } \\
\text { façade area. } \\
\text { Using } \\
\text { negative } \\
\text { suction } \\
\text { pressure on } \\
\text { the } \\
\text { courtyard's } \\
\text { roof opening } \\
\text { as a } \\
\text { ventilation } \\
\text { strategy. }\end{array}$ & $\begin{array}{l}\text { Enabling large pressure } \\
\text { field on the roof by } \\
\text { shading the courtyard } \\
\text { with a porous roof to } \\
\text { create stronger } \\
\text { ventilation pressure } \\
\text { differentials. Roofs that } \\
\text { are placed near } \\
\text { atmospheric pressure } \\
\text { (positive experience) } \\
\text { poorly performed } \\
\text { compared to roofs } \\
\text { exposed to negative } \\
\text { pressure when the wind } \\
\text { is perpendicular to the } \\
\text { building. Most of the } \\
\text { courtyard roofs are } \\
\text { carried out with the same } \\
\text { standard at oblique wind } \\
\text { direction (45 }{ }^{\circ} \text { ) [26] }\end{array}$ \\
\hline $\begin{array}{l}\text { Daytime } \\
\text { ventilation }\end{array}$ & $\begin{array}{l}\text { Better indoor } \\
\text { thermal } \\
\text { adjustment } \\
\text { when } \\
\text { courtyard } \\
\text { functions as } \\
\text { an opened air } \\
\text { funnel. }\end{array}$ & $\begin{array}{l}\text { The direction of the } \\
\text { external wind flow of } 45 \\
{ }^{\circ} \text { through the building } \\
\text { opening gives the air } \\
\text { flow in the room higher } \\
\text { than the normal direction } \\
\left(0^{\circ}\right)[26] \\
\text { Reducing temperatures } \\
\text { to } 2^{\circ} \mathrm{C} \text { under the } \\
\text { maximum outdoors } \\
\text { compared to the } \\
\text { courtyard without } \\
\text { ventilation }\left(0.7^{\circ} \mathrm{C}\right) \\
\text { during daytime } \\
\text { ventilation. } \\
\text { The optimal } \mathrm{ACH} \text { is } \\
\text { between } 1.5-2 \mathrm{ACH} \\
\text { when the thermal } \\
\text { modification is } 1^{\circ} \mathrm{C}\end{array}$ \\
\hline
\end{tabular}

\begin{tabular}{|c|c|c|}
\hline Elements & Criterions & Performance \\
\hline & & $\begin{array}{l}\text { under the ambient level } \\
\text { [27]. }\end{array}$ \\
\hline $\begin{array}{l}\text { Courtyard } \\
\text { ratio }\end{array}$ & $\begin{array}{l}\text { Larger } \\
\text { courtyard } \\
\text { ratio (width to } \\
\text { height) } \\
\text { generated } \\
\text { better flow } \\
\text { for indoor. }\end{array}$ & $\begin{array}{l}\text { The presence of open } \\
\text { windows in a narrow } \\
\text { courtyard produces more } \\
\text { than one vortex to } \\
\text { coincide with the } \\
\text { number of the floors. } \\
\text { Conversely, in more } \\
\text { extensive courtyard, the } \\
\text { impact of an open } \\
\text { window to the air flow in } \\
\text { the cavity is less } \\
\text { noticeable. As a result, } \\
\text { the primary vortex inside } \\
\text { the courtyard is not } \\
\text { affected [28]. The form } \\
\text { of a building with } \\
\text { medium depth at almost } \\
\text { any elongation value, } \\
\text { preferably for acceptable } \\
\text { performance [29] }\end{array}$ \\
\hline $\begin{array}{l}\text { Ventilation } \\
\text { Mechanism }\end{array}$ & $\begin{array}{l}\text { In providing a } \\
\text { higher level } \\
\text { of building } \\
\text { ventilation, } \\
\text { cross } \\
\text { ventilation } \\
\text { has better } \\
\text { performance } \\
\text { compared to } \\
\text { the one-sided } \\
\text { ventilation } \\
\text { mechanism. }\end{array}$ & $\begin{array}{l}\text { The one-facing rooms } \\
\text { and single natural } \\
\text { ventilation have very } \\
\text { low indoor airspeeds. } \\
\text { In a one-sided ventilated } \\
\text { room, the sun protection } \\
\text { factor is an important } \\
\text { role in maintaining } \\
\text { indoor conditions even at } \\
\text { higher temperatures [28]. } \\
\text { Continuous ventilation } \\
\text { helps to control the level } \\
\text { of humidity in the } \\
\text { building [30]. }\end{array}$ \\
\hline Orientation & $\begin{array}{l}\text { The axial of } \\
\text { the courtyard } \\
\text { spans to } \\
\text { northeast- } \\
\text { southwest } \\
\text { side. }\end{array}$ & $\begin{array}{l}\text { Hot-humid: Optimal } \\
\text { shade happens when the } \\
\text { yard is posited at } \\
\text { northeast-southwest } \\
\text { (estimated } 65 \% \text { shade } \\
\text { area) [29]. } \\
\text { Lower air temperature } \\
\text { than the outdoor in the } \\
\text { north and south ( } 2 \% \\
\text { lower) [32]. }\end{array}$ \\
\hline $\begin{array}{l}\text { Courtyard } \\
\text { Height }\end{array}$ & $\begin{array}{l}\text { Highest } \\
\text { courtyard } \\
\text { lowers the air } \\
\text { temperature. }\end{array}$ & $\begin{array}{l}\text { The optimal courtyard is } \\
\text { found on the third floor } \\
\text { in a hot humid climate } \\
\text { [29]. } \\
\text { Significant height effect } \\
\text { of the courtyard wall at } \\
\text { air temperature [32]. } \\
\text { Decreasing the height of } \\
\text { courage increase the } \\
\text { average temperature of } \\
\text { radiation during the day } \\
\text { [19] }\end{array}$ \\
\hline $\begin{array}{l}\text { Shading } \\
\text { Device }\end{array}$ & $\begin{array}{l}\text { The shade is } \\
\text { adjacent to } \\
\text { the opening in } \\
\text { the room }\end{array}$ & $\begin{array}{l}\text { Air temperature is } 1.5^{\circ} \mathrm{C} \\
\text { lower compared to } \\
\text { maximum outdoor } \\
\text { (Synchronization with }\end{array}$ \\
\hline
\end{tabular}




\begin{tabular}{|c|c|c|}
\hline Elements & Criterions & Performance \\
\hline & & $\begin{array}{l}\text { upper courtyard } \\
\text { temperature) [30]. }\end{array}$ \\
\hline Roof height & $\begin{array}{l}\text { The elevated } \\
\text { courtyard } \\
\text { with a height } \\
\text { of } 500 \mathrm{~mm}\end{array}$ & $\begin{array}{l}\text { Reducing courtyard heat } \\
\text { gain during peak hours } \\
\text { (1:00 p.m.) around } 85 \% \\
\text { and increasing thermal } \\
\text { conditions in adjacent } \\
\text { zones [31] }\end{array}$ \\
\hline $\begin{array}{l}\text { Canopy of } \\
\text { trees }\end{array}$ & $\begin{array}{l}\text { Tree canopy } \\
\text { adjacent to } \\
\text { the window. }\end{array}$ & $\begin{array}{l}\text { Lower indoor means } \\
\text { adjacent room } \\
\text { temperature with } \\
\text { relatively higher } \\
\text { humidity [33]. } \\
\text { Cover with the highest } \\
\text { temperature levels and } \\
\text { an average increase rate } \\
\text { for relative humidity } \\
\text { compared to the } \\
\text { courtyard with the } \\
\text { vacant lot [19] }\end{array}$ \\
\hline $\begin{array}{l}\text { Night } \\
\text { ventilation }\end{array}$ & $\begin{array}{l}\text { Night } \\
\text { ventilation is } \\
\text { superior to } \\
\text { others, e.g., } \\
\text { Full day, } \\
\text { noon, and no } \\
\text { ventilation. }\end{array}$ & $\begin{array}{l}\text { The average temperature } \\
\text { is always below } 30^{\circ} \mathrm{C} \\
\text { comparable to the others. }\end{array}$ \\
\hline $\begin{array}{l}\text { The Sky } \\
\text { exposure }\end{array}$ & $\begin{array}{l}\text { Proper design } \\
\text { consideration } \\
\text { s from sky } \\
\text { exposure can } \\
\text { offer the } \\
\text { desired } \\
\text { shadow effect } \\
\text { and allow } \\
\text { ventilation } \\
\text { circulation }\end{array}$ & $\begin{array}{l}\text { Increasing the } \\
\text { courtyard's sky view } \\
\text { factor increase the air } \\
\text { temperature [34]. }\end{array}$ \\
\hline $\begin{array}{l}\text { Night } \\
\text { ventilation } \\
\text { and } \\
\text { courtyard's } \\
\text { sloped } \\
\text { roofs }\end{array}$ & $\begin{array}{l}\text { The } \\
\text { application of } \\
\text { night } \\
\text { ventilation } \\
\text { and sloping } \\
\text { roofs on the } \\
\text { courtyard can } \\
\text { be the right } \\
\text { method to } \\
\text { maintain } \\
\text { lower indoor } \\
\text { conditions } \\
\text { compared to } \\
\text { outdoors. }\end{array}$ & $\begin{array}{l}\text { Night time ventilation } \\
\text { can ensure cold air is } \\
\text { provided to indoor } \\
\text { spaces, while a sloping } \\
\text { roof can increase the } \\
\text { flow of cold air due to } \\
\text { the effect of cooling } \\
\text { radiation at night [34]. }\end{array}$ \\
\hline Shading & $\begin{array}{l}\text { Consideration } \\
\text { of the effect } \\
\text { of shade by } \\
\text { controlling } \\
\text { exposure to } \\
\text { the sky or } \\
\text { roof of the } \\
\text { courtyard is } \\
\text { expected to } \\
\text { be more } \\
\text { appropriate. }\end{array}$ & $\begin{array}{l}\text { In hot humid climates, } \\
\text { diffuse sun radiation } \\
\text { exposure affected heat } \\
\text { gain for courtyard space. } \\
\text { Therefore, building } \\
\text { orientation can be less } \\
\text { significant than direct } \\
\text { exposure or direct } \\
\text { shading devices [35] }\end{array}$ \\
\hline
\end{tabular}

\section{METHOD}

Objects of the study are six boarding houses by Andy Rahman Architect, which conducted using field measurement. Andy Rahman, the founder and principal architect of Andy Rahman Architect, is an influential architect in the architecture industry of Indonesia. His works were published in both national and international media. In 2012, he was granted a world-level architecture award as a nominee in Architizer A + Awards. Furthermore, his Biophilic Boarding house was also nominated as a finalist in the World Architecture Festival 2016 in Berlin and Archdaily's Building of the Year 2017. The six boarding houses are Andy Rahman's works since 2014 which are located in one nearly residential area. One of its unique features is the use of ventilated block and courtyard as passive cooling strategies.

The field measurement was taken place in Keputih boarding houses that consist of two and three-storey boarding houses, located in Surabaya $\left(7.17^{\circ} \mathrm{S}\right.$ and $\left.112.48^{\circ} \mathrm{E}\right)$ at the position of approximately $1.5 \mathrm{~m}$ above sea level. As shown in Fig. 1, Keputih boarding houses consist of six boarding houses (Keputih boarding houses $1,2,3,4,5$, and 6) which located in the middle of the row with a narrow frontage $(6 \mathrm{~m}-12 \mathrm{~m})$ and a long depth $(15 \mathrm{~m}-25 \mathrm{~m})$. The measurement was conducted throughout 22nd March to 12th April 2019 for Keputih boarding house 1 and 28th May to 20th June 2019 for Keputih boarding house $2,3,4,6$. The monthly temperatures extend from $27.2^{\circ} \mathrm{C}$ (November) to $30.3^{\circ} \mathrm{C}$ (April), and relative humidity ranges between $70-80 \%$.

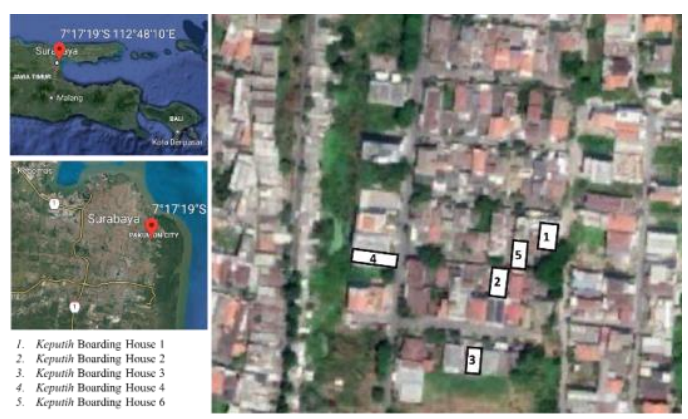

Figure 1: Location of case study boarding house (source: Google Earth, retrieved on 26 June 2019)

The main features of Keputih boarding houses are the use of ventilated blocks on its façade and the availability of courtyard in Keputih boarding house 2,3 , and 6 , as shown in figure 2 . The use of ventilated blocks shows that all the objects are using full day ventilation. Fig. 3 shows the case study's floor plans. Floor-to-floor height in all buildings is $3.7 \mathrm{~m}$, with wall and floor materials 
are made of brick and concrete respectively. RC4HC Elitech data loggers are used to measure the air temperature and relative humidity. The measurement accuracy is $\pm 0.5^{\circ} \mathrm{C}$ from $-30-60^{\circ} \mathrm{C}$ for air temperature and $\pm 3 \%$ over $0-99 \%$ relative humidity. Moreover, the sensors were shaded with aluminum foil cups to protect from solar radiation. The measurements were recorded every hour over the 23 days. The position of measurement was at $1.5 \mathrm{~m}$ above the floor level and in the center on the courtyard (refer Fig. 3). The boarding house that has three courtyards is Keputih boarding house 2, 3, and 6. Hence, in this case, more measurement devices were put in the courtyard to know the vertical air temperature. Fig. 3 and 4 show the position of the devices.

The comfort temperature or neutral temperature is estimated from the linear equation for naturally ventilated building as mentioned in Nugroho [36]: $\mathrm{Tn}=17.8+0.31 \mathrm{x}$ Tamt, where, $\mathrm{Tn}=$ neutral temperature with $+/-2^{\circ} \mathrm{K}$ range and Tamt $=$ annual mean temperature of the month. The overview of Indonesia's comfort zone range is obtained through comparative comfort zone using the above equation and the annual average temperature using the Indonesia's climate data. Conforming to Auliciems and Szokolay [37], the range of the comfort zone is $5^{\circ} \mathrm{C}$, which extends $+/-2.5^{\circ} \mathrm{C}$ of the neutral temperature.

Table 2: The Parameters of Case Studies Boarding House

\begin{tabular}{|l|l|l|l|l|l|}
\hline No & $\begin{array}{l}\text { Name of } \\
\text { Building }\end{array}$ & Orientation & Size & $\begin{array}{l}\text { Number } \\
\text { of floors }\end{array}$ & Built \\
\hline 1 & $\begin{array}{l}\text { Keputih } \\
\text { Boarding } \\
\text { House 1 }\end{array}$ & North-south & $12 \times 15$ & 2 & 2014 \\
\hline 2 & $\begin{array}{l}\text { Keputih } \\
\text { Boarding } \\
\text { House 2 }\end{array}$ & North-south & $8 \times 15$ & 2 & 2015 \\
\hline 3 & $\begin{array}{l}\text { Keputih } \\
\text { Boarding } \\
\text { House 3 }\end{array}$ & North-south & $12 \times 20$ & 2 & 2016 \\
\hline 4 & $\begin{array}{l}\text { Keputih } \\
\text { Boarding } \\
\text { House 4 }\end{array}$ & West-east & $6 \times 25$ & 3 & 2017 \\
\hline 5 & $\begin{array}{l}\text { Keputih } \\
\text { Boarding } \\
\text { House 6 }\end{array}$ & North-south & $8 \times 15$ & 3 & 2018 \\
\hline
\end{tabular}

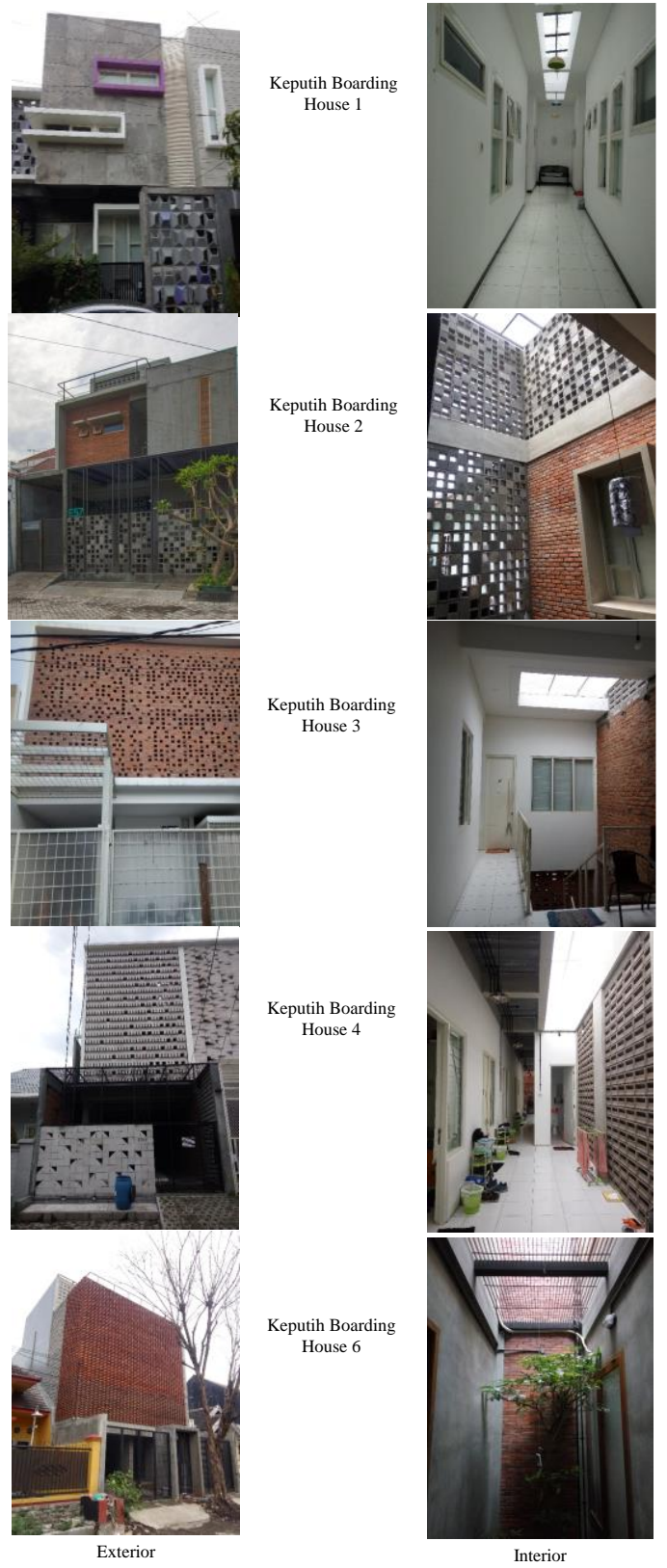

Figure 2: Front exterior and interior view of Keputih boarding house 


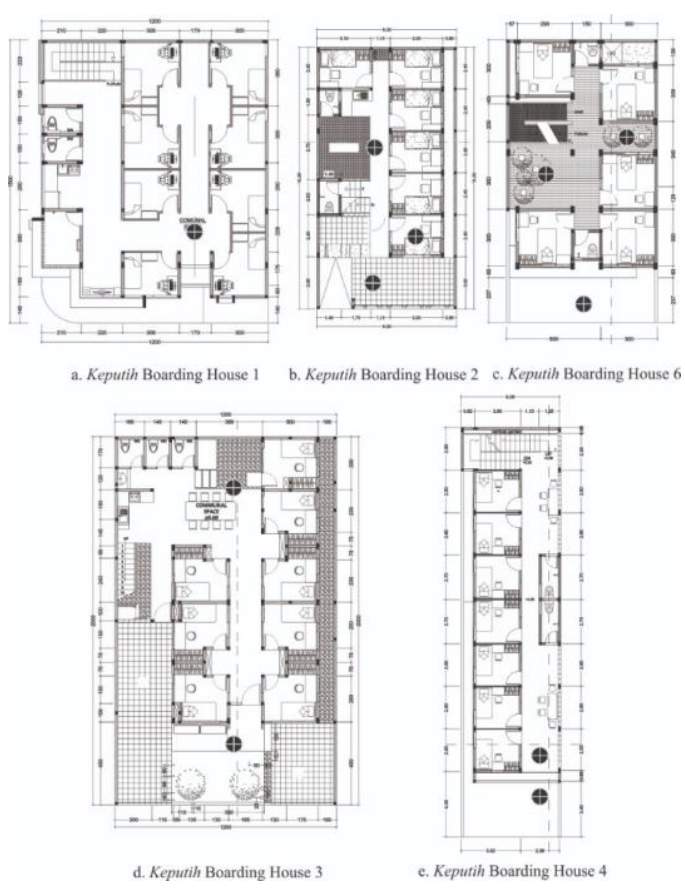

Figure 3:Floor plan of case study Keputih boarding house

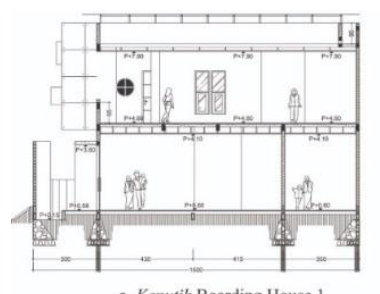

a. Keputih Boarding House

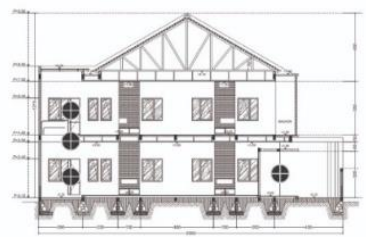

c. Keputih Boarding House 3

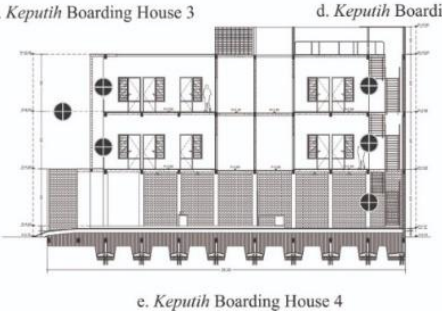

Figure 4: Section plan of Keputih boarding house

\section{RESULT AND DISCUSSION}

\subsection{Evaluation of Surabaya Neutral Temperature}

Responsive building design strategies are required in a tropical climate to achieve thermal comfort by considering its daily conditions. The monthly data of outdoor temperature is presented in Figure 5. The highest outdoor temperature is $30^{\circ} \mathrm{C}$ in November, while the lowest is $26.5^{\circ} \mathrm{C}$ in August, with the average temperature is around $28.2^{\circ} \mathrm{C}$. According to Szokolay's comfort formula [37], the required neutral temperature to be maintained is at $26.3^{\circ} \mathrm{C}$. Based on the range of comfort zone, which is $+/-2.5^{\circ} \mathrm{C}$ of the neutral temperature, the neutral temperature of $26.3^{\circ} \mathrm{C}$ has a comfort zone with $23.8^{\circ} \mathrm{C}$ as the lower limit and $28.8^{\circ} \mathrm{C}$ as the upper limit. This neutral temperature is applied under the condition of no air movement. The high mean air velocity in Surabaya $(<1 \mathrm{~m} / \mathrm{s})$ can be used to expand the comfort zone to $32.0^{\circ} \mathrm{C}$.

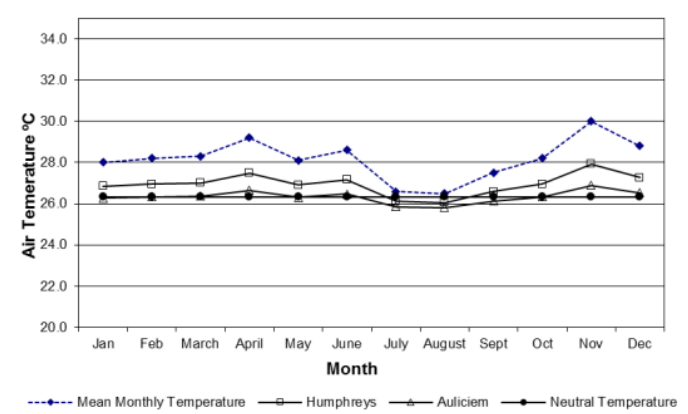

Figure 5: The Neutral temperature on the Surabaya monthly data.

\subsection{Indoor Air Temperature in Case Keputih Boarding House 1, 3, 4 and 6}

The temperature and humidity in the corridor over the entire measurement period with the corresponding outdoor air temperature conditions are shown in figure 6. It shows that the outdoor air temperature varies from $25.4-35.9^{\circ} \mathrm{C}$ with an average of $30.3^{\circ} \mathrm{C}$, while the relative humidity extends between $50.3-82.4 \%$. The indoor air temperature in four boarding houses varies nearly in parallel. At daytime, the indoor air temperatures are approximately $2.7-4.6^{\circ} \mathrm{C}$ lower than the corresponding outdoor air temperature, while the temperatures at nighttime are slightly higher than the outdoors by $0.2-1.1^{\circ} \mathrm{C}$.

Fig.6a shows there is no time lag in Keputih boarding house 1 due to the existence of a roof as a heat barrier, as usually seen in a traditional building. On the other hand, the time lag is shown in Keputih boarding house 3, 4, and 6, which use 
the concrete roof. The highest time lag is 3 hours in Keputih boarding house 6, with both Keputih boarding houses 3 and 4 have 2 hours lags. This corresponds with research by Dili [30] and Sadafi et al. [31], which stated that the delay in transmitting heat to the interiors through the roof could result in a time lag.
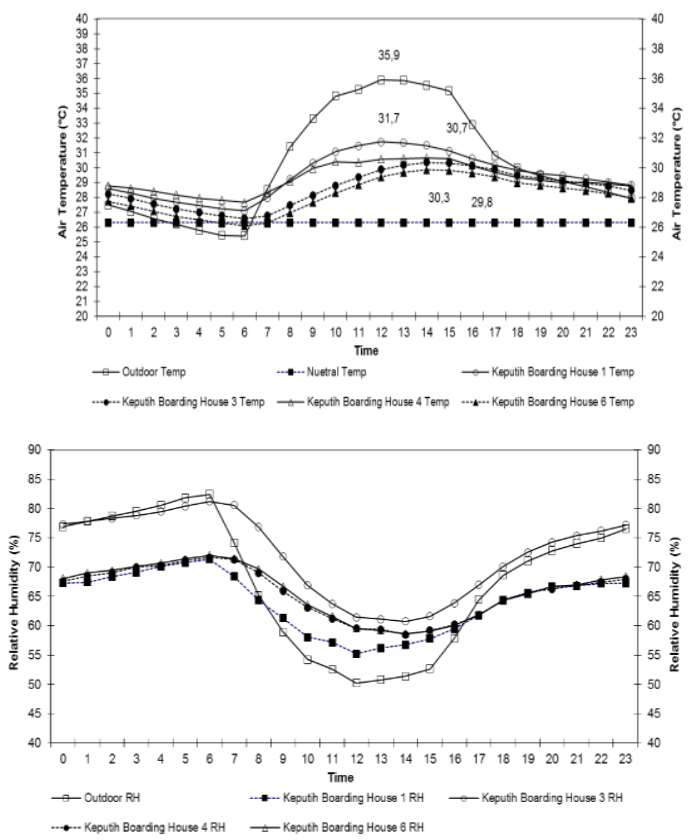

Figure 6: Temporal variations of indoor air temperature (top) and relative humidity (bottom) in the communal space (2nd floor) at $1.5 \mathrm{~m}$ above the floor

The results indicated that the air temperature in the four boarding houses largely exceeds the upper limits more than $50 \%$ of the measurement period, especially during the daytime. It suggests that the indoor neutral temperature cannot be achieved in most of the daytime hours by solely relying on thermal adaptation in a hot-humid climate. Further consideration of wind velocity effects is required. Of all four boarding houses, only two boarding houses performed a better temperature reduction, Keputih boarding house 3 and house 6 , which owned courtyards.

\subsection{Courtyard Air Temperature in Case Keputih Boarding House 3 and 6}

Fig.7.a shows that the outdoor and indoor air temperatures were nearly the same, around $28^{\circ} \mathrm{C}$ at 18:00. During daytime $(09.00 \mathrm{~h} ; 12.00 \mathrm{~h} ; 15.00$ $\mathrm{h})$, the air temperatures in the communal space and outdoor are higher than the courtyard. Meanwhile, during nighttime $(00.00 \mathrm{~h} ; 03.00 \mathrm{~h}$, $21.00 \mathrm{~h}$ ), the air temperatures in the courtyard and outdoors were lower than the communal space. In the communal space of the Keputih boarding house, a slightly warmer air temperature of $26.6^{\circ} \mathrm{C}-28.1^{\circ} \mathrm{C}$ was discovered.

On the contrary, Fig.7.b shows that the outdoor air temperatures were higher than the indoors at 09:00, 12:00, 15:00, and 18:00. In contrast with Keputih boarding house 3, in Keputih boarding house 6 , the indoor and outdoor air temperature was relatively the same at 21:00. This similarity indicates that the time lag case in Keputih boarding house 6 is longer than in Keputih boarding house 3 . The indoor air temperatures are warmer at 00:00, 03:00, and 06:00. Fig.7 shows that the air temperature in the courtyard followed the same pattern with the outdoor temperature. The reduction of air temperature in the courtyard below the outdoor temperature level was discovered in both cases, Keputih boarding houses 3 and 6 , due to their high-mass and fullday ventilated buildings.
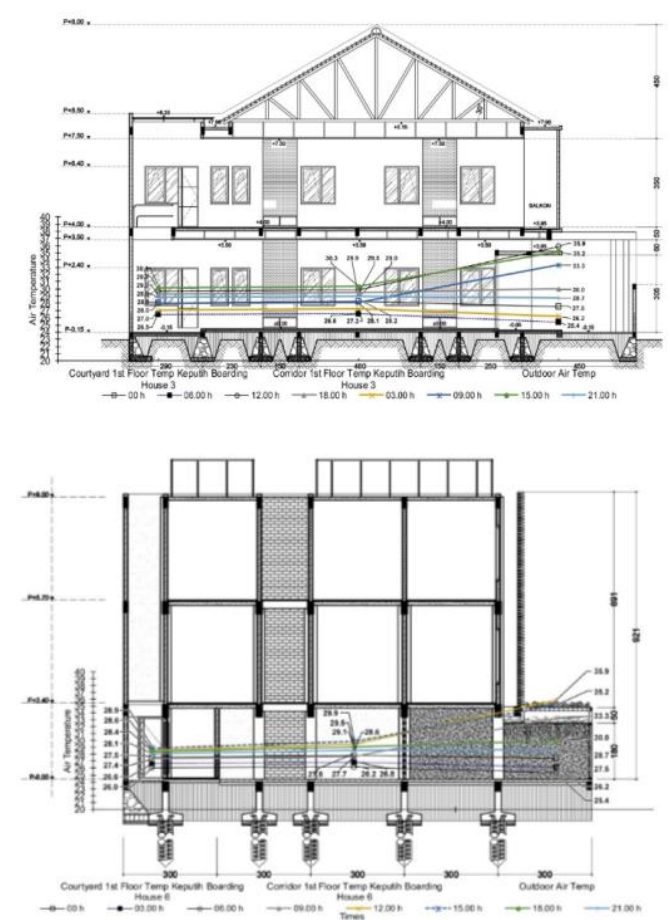

Figure 7: Average air temperatures in different space at 1.5 $\mathrm{m}$ above floor) over the period $(00.00 \mathrm{~h} ; 03.00 \mathrm{~h} ; 09.00 \mathrm{~h}$; $12.00 \mathrm{~h} ; 15.00 \mathrm{~h} ; 18.00 \mathrm{~h}, 21.00 \mathrm{~h}$ ) in case Keputih Boarding House 3 (top) and Keputih Boarding House 6 (bottom).

\subsection{Vertical Air Temperature in the Courtyards for the Case Keputih Boarding House 3 \& 6}

The vertical air temperature profile in the courtyard of Keputih boarding house 3 and 6 can be seen in fig. 8 . The results show a different pattern of stratification during daytime and nighttime in both cases. However, the highest daytime temperature of $31.5^{\circ} \mathrm{C}$ at the top level in the courtyard increased along with the temperature of $28.9^{\circ} \mathrm{C}$ and $30.4^{\circ} \mathrm{C}$ in the first and 
second courtyard, respectively, in case Keputih Boarding House 6. Meanwhile, the highest temperature at the top-level was lower than the highest outdoor air temperature of $35.5^{\circ} \mathrm{C}$. The vertical temperature profile shows a heat gain from the first courtyard is rising or retreating to the top. Furthermore, the air temperature reduction at the bottom and middle levels in the courtyard are more significant in Keputih boarding house 6 case, from $3^{\circ} \mathrm{C}$ to $4^{\circ} \mathrm{C}$, than in Keputih boarding house 3 case, from $5^{\circ} \mathrm{C}$ to $6^{\circ} \mathrm{C}$.

Thermal stratification is shown in both Keputih boarding house 3 and house 6 cases. The highest temperature at the top level is higher compared to the upper floor. In the Keputih boarding house 6 case, the relatively lower air temperature levels were recorded in the first-floor courtyard. The gradient of the air temperature above was also observed during nighttime, except in the courtyard of Keputih boarding house 3 (Fig. 8). The courtyard in Keputih boarding house 6 gives the effect of vertical air exchange, which results in air temperature being reduced adequately to the outdoor levels. These results indicate that the outdoor air that is relatively cool at night is most likely to enter the buildings from the upper openings of the courtyard, consisting of ventilated blocks and effectively cool the structure of the building at night.
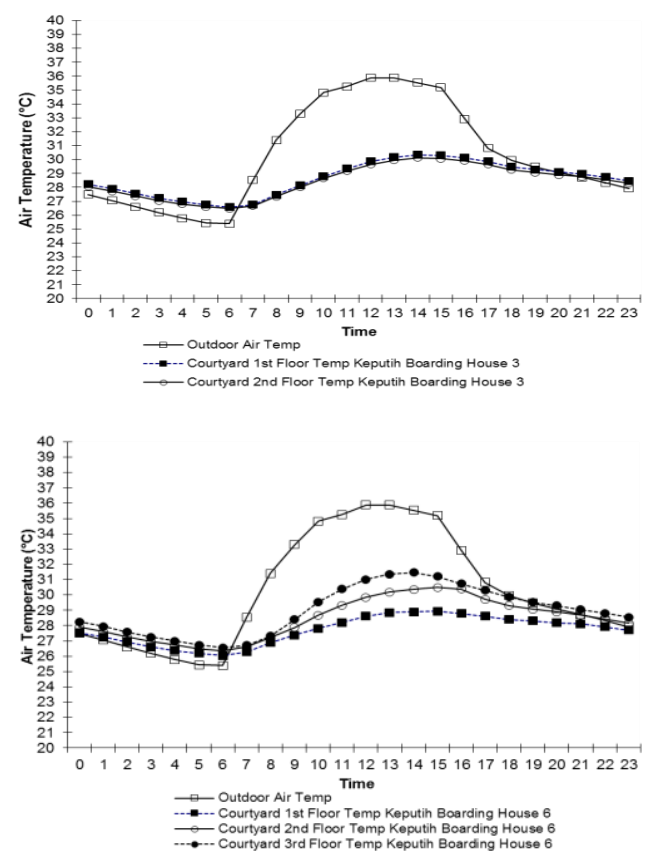

Figure 8: Average vertical air temperature in the courtyard over the period $(00.00 \mathrm{~h}$; $03.00 \mathrm{~h} ; 09.00 \mathrm{~h} ; 12.00 \mathrm{~h} ; 15.00 \mathrm{~h} ; 18.00 \mathrm{~h}$, $21.00 \mathrm{~h}$ ) ) in case Keputih Boarding House 3 (top) and Keputih Boarding House 6 (bottom).

\subsection{Thermal Environments in the Courtyard, Corridor and the Bedroom in Case Keputih Boarding House 2 and 6}

The following discussion is the results of thermal environment field measurement on two different study cases with different measured times, Keputih boarding house 2 from 21 March-21 April 2019 and Keputih boarding house 6 from 28 May-20 June 2019. The bedroom adjacent to the courtyard is directly affecting the courtyard's thermal environment. Therefore, this zone's indoor air temperature is observed and compared with the courtyard and outdoor air temperatures to understand the courtyard's effect on the indoor environment. As presented in Fig. 9, the indoor air temperatures were lower than the courtyard levels during the daytime in both Keputih boarding house 2 and 6 cases. However, while the indoor air temperatures parallel with the courtyard temperature, during the Keputih boarding house 2 case (except in the early morning), the indoor air temperatures were relatively lower than the indicated levels in Keputih boarding house 6 . It correlates with the pattern of courtyard temperature compared to the outdoor temperature. The highest indoor air temperature in Keputih boarding house case 2 and 6 are $28.6^{\circ} \mathrm{C}$ at $19: 00$ and $28.8^{\circ} \mathrm{C}$ during 14:00-16:00 $\mathrm{h}$ respectively.

The maximum air temperature of the courtyard and the outdoor were recorded at the same time by 12:00 $\mathrm{h}$ in Keputih boarding house 2 case with a temperature of $31.6^{\circ} \mathrm{C}$ and $33.5^{\circ} \mathrm{C}$ respectively. These temperatures show a slight temperature reduction of $1.9^{\circ} \mathrm{C}$. Meanwhile, for the Keputih boarding house 6 case, the maximum air temperature of the courtyard is decreased by $5.7^{\circ} \mathrm{C}$ below the maximum air temperature of outdoor by 14:00h, 2 hours after the maximum air temperature of outdoor was recorded. Furthermore, this indicates a relatively more significant reduction of air temperatures in the Keputih boarding house 6 case corresponds with the daytime indoor temperature induction.

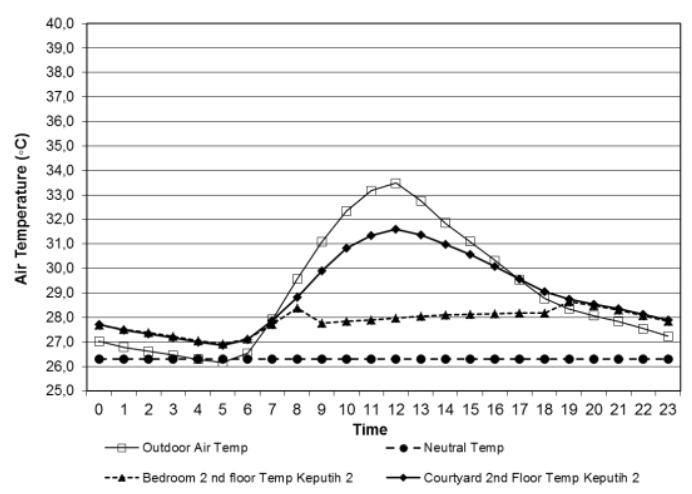




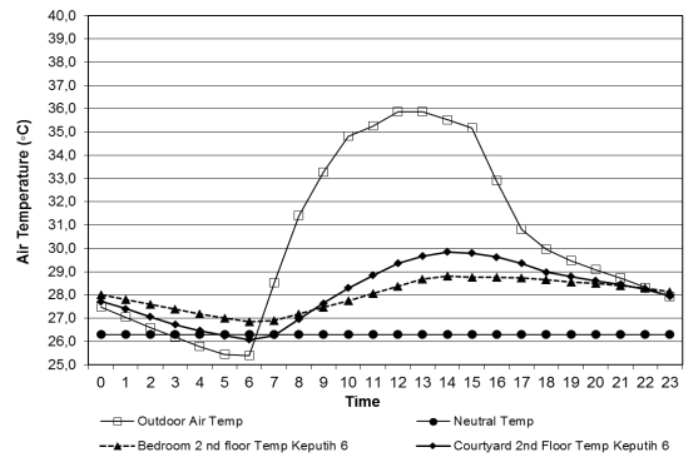

Figure 9: Temporal variations of indoor air temperature in the bedroom and communal space with the corresponding neutral temperature (at $1.5 \mathrm{~m}$ above the floor) in case Keputih Boarding House 2 (top) and Keputih Boarding House 6 (bottom).

\subsection{The Impact of Roof Opening, Ventilation Mode and Number of Floor for Air Temperature Reduction}

The influence of the floors' level on temperature reduction is shown in fig. 10. Keputih boarding house 6 with 3 -storey height shows a higher performance of temperature reduction on the ground floor compared to the Keputih boarding house 3 with 2 -storey height. The maximum temperature reduction of the first-floor courtyard in Keputih boarding houses 6 and 3 is $7.3^{\circ} \mathrm{C}$ and $6^{\circ} \mathrm{C}$, respectively.

The influence of the floors number and the courtyard heights reinforces the results of Muhaisen [29] study, which stated a courtyard would perform efficiently with three-storey height. This statement is also following the research of Sadafi [31] and Almhafdy et al. [32], which stated the addition of shaded roof for the courtyard would reduce the solar heat gains.

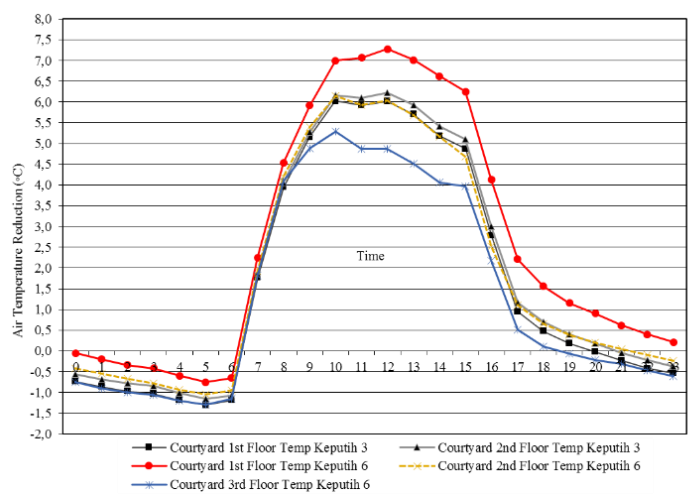

Figure 10: Air Temperature Reduction between Outdoor Air Temperature with the center of courtyard air temperatures in case Keputih Boarding House 3 and 6.
The air temperature of the courtyard with the influence of openings on the roof shows a difference in vertical air temperature performance. The courtyard with a large ventilated roof gives stack effect ventilation, indicated by the temperature difference between the lower and upper floors in Keputih boarding house 2. Meanwhile, in Keputih boarding house 3 , the temperature between the lower and upper levels are relatively the same.
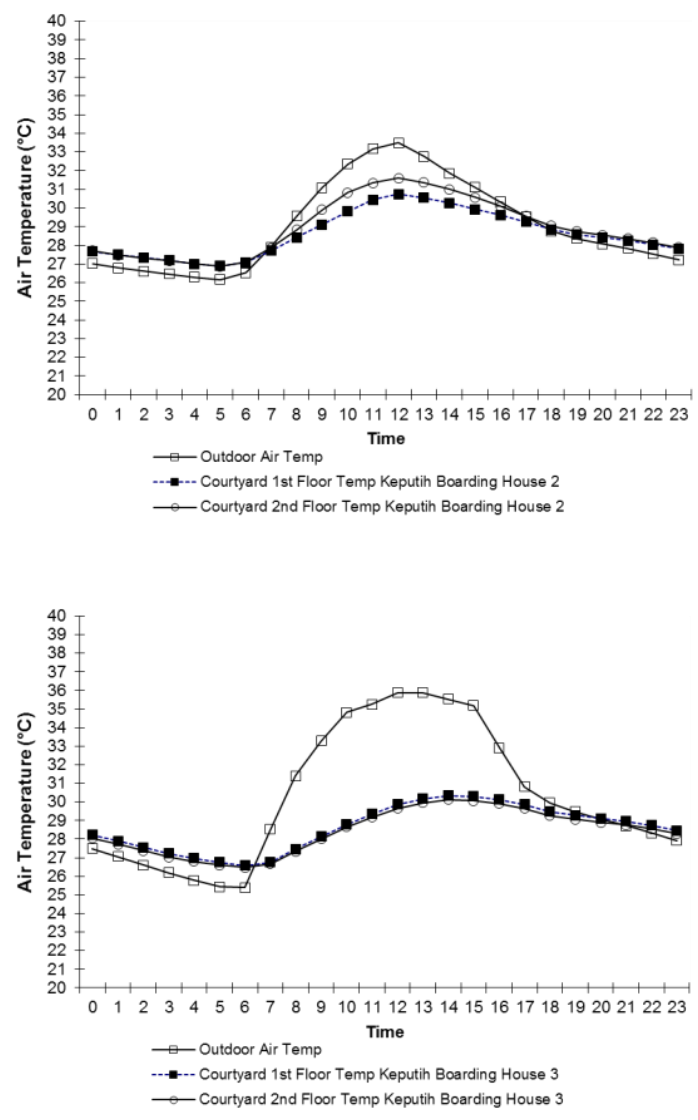

Figure 11: Courdyard air temperature profile in case Keputih boarding house 2 (top) and Keputih boarding house 3 (bottom).

The influence of the roof openings in this study follows the results study of Sharples and Bensalem [26], which stated the courtyard roof model with a porosity of $11,4 \%$ conflicted with the generated negative pressure forces on the leeward wall of the model. This phenomenon occurred in the Keputih boarding house case 3, which has a higher roof wall and a larger opening ratio than the Keputih boarding house 2 . 


\section{CONCLUSION}

The results indicated that with the application of courtyard, the indoor air temperatures were approximately lower than the outdoor air temperature by $4.9-7.3{ }^{\circ} \mathrm{C}$ during $12.00 \mathrm{~h}$. The passive cooling effect in the courtyard was also increased due to the ventilated block as full-day ventilation. During nighttime, indoor air temperatures were slightly higher than the outdoors by $0.8-1.3^{\circ} \mathrm{C}$ during 05:00 $\mathrm{h}$. The thermal environment evaluation results revealed that indoor air temperatures are categorized as a neutral temperature of the measurement period. Thus, the use of courtyards in contemporary boarding houses has proven as a feasible means to achieve sufficient cooling effects through a full-day ventilation strategy and showed improved performance when combined with ventilated blocks.

\section{ACKNOWLEDGMENT}

The research through a research grant from University of Brawijaya, Indonesia.

\section{REFERENCES}

1. A. N. Sadeghifam, S. M. Zahraee, M. M. Meynagh, and I. Kiani, "Combined use of design of experiment and dynamic building simulation in assessment of energy efficiency in tropical residential buildings," Energy Build., vol. 86, pp. 525-533, 2015.

2. S. Moghimi, F. Azizpour, S. Mat, C. H. Lim, E. Salleh, and K. Sopian, "Building energy index and end-use energy analysis in large-scale hospitals-case study in Malaysia," Energy Effic., vol. 7, no. 2, pp. 243-256, 2014.

3. A. G. Noble, Traditional buildings: a global survey of structural forms and cultural functions. Ne York: I.B. Tauris \& Co Ltd, 2007.

4. S. Teshnehdel, S. Mirnezami, A. Saber, A. Pourzangbar, and A. G. Olabi, "Datadriven and numerical approaches to predict thermal comfort in traditional courtyards," Sustain. Energy Technol. Assessments, vol. 37, p. 100569, 2020.

5. O. Al-Hafith, B. K. Satish, S. Bradbury, and P. De Wilde, "The Impact of Courtyard parameters on its shading level An experimental study in Baghdad, Iraq," in Energy Procedia, 2017, vol. 134, pp. 99109.

6. F. Soflaei, M. Shokouhian, and S. M. Mofidi Shemirani, "Investigation of Iranian traditional courtyard as passive cooling strategy (a field study on BS climate)," Int. J. Sustain. Built Environ., vol. 5, no. 1, pp. 99-113, 2016.

7. F. B. M. Baboli, N. Ibrahim, and D. M. Sharif, "Design Characteristics and Adaptive Role of the Traditional Courtyard Houses in the Moderate Climate of Iran," in Procedia - Social and Behavioral

8. Khajehzadeh, B. Vale, and F. Yavari, "A comparison of the traditional use of court houses in two cities," Int. J. Sustain. Built Environ., vol. 5, no. 2, pp. 470-483, 2016.

9. F. Soflaei, M. Shokouhian, H. Abraveshdar, and A. Alipour, "The impact of courtyard design variants on shading performance in hot- arid climates of Iran," Energy Build., vol. 143, pp. 71-83, 2017.

10. F. Soflaei, M. Shokouhian, and A. Soflaei, "Traditional courtyard houses as a model for sustainable design: A case study on BWhs mesoclimate of Iran," Front. Archit. Res., vol. 6, no. 3, pp. 329-345, 2017.

11. F. Soflaei, M. Shokouhian, A. Tabadkani, H. Moslehi, and U. Berardi, "A simulationbased model for courtyard housing design based on adaptive thermal comfort," $J$. Build. Eng., vol. 31, p. 101335, 2020.

12. M. S. Guedouh, N. Zemmouri, A. Hanafi, and R. Qaoud, "Passive strategy based on courtyard building morphology impact on thermal and luminous environments in hot and arid region," in Energy Procedia, 2019, vol. 157, pp. 435-442.

13. G. Maniołlu and G. Koçlar Oral, "Effect of courtyard shape factor on heating and cooling energy loads in hot-dry climatic zone," in Energy Procedia, 2015, vol. 78, pp. 2100-2105.

14. F. Soflaei, M. Shokouhian, and W. Zhu, "Socio-environmental sustainability in 
traditional courtyard houses of Iran and China," Renew. Sustain. Energy Rev., vol. 69, pp. 1147-1169, 2017.

15. F. Amirbeiki Tafti, M. Rezaeian, and S. Z. Emadian Razavi, "Sunken courtyards as educational environments: Occupant's perception and environmental satisfaction," Tunn. Undergr. Sp. Technol., vol. 78, pp. 124-134, 2018.

16. F. Soflaei, M. Shokouhian, and S. M. Mofidi Shemirani, "Traditional Iranian courtyards as microclimate modifiers by considering orientation, dimensions, and proportions," Front. Archit. Res., vol. 5, no. 2, pp. 225-238, 2016.

17. J. Rodríguez-Algeciras, A. Tablada, M. Chaos-Yeras, G. De la Paz, and A. Matzarakis, "Influence of aspect ratio and orientation on large courtyard thermal conditions in the historical centre of Camagüey-Cuba," Renew. Energy, vol. 125, pp. 840-856, 2018.

18. T. Kubota, M. A. Zakaria, S. Abe, and D. H. C. Toe, "Thermal functions of internal courtyards in traditional Chinese shophouses in the hot-humid climate of Malaysia," Build. Environ., vol. 112, pp. 115-131, 2017.

19. A. Ghaffarianhoseini, U. Berardi, and A. Ghaffarianhoseini, "Thermal performance characteristics of unshaded courtyards in hot and humid climates," Build. Environ., vol. 87, pp. 154-168, 2015.

20. A. Almhafdy, N. Ibrahim, S. S. Ahmad, and J. Yahya, "Thermal Performance Analysis of Courtyards in a Hot Humid Climate Using Computational Fluid Dynamics CFD Method," in Procedia Social and Behavioral Sciences, 2015, vol. 170, pp. 474-483.

21. M. A. Zakaria, T. Kubota, and D. H. C. Toe, "The Effects of Courtyards on Indoor Thermal Conditions of Chinese Shophouse in Malacca," in Procedia Engineering, 2015, vol. 121, pp. 468-476.

22. Z. Li, D. H. C. Chow, J. Yao, X. Zheng, and W. Zhao, "The effectiveness of adding horizontal greening and vertical greening to courtyard areas of existing buildings in the hot summer cold winter region of China: A case study for Ningbo," Energy Build., vol. 196, pp. 227-239, 2019.

23. F. Wang, F. Yu, X. Zhu, X. Pan, R. Sun, and H. Cai, "Disappearing gradually and unconsciously in rural China: Research on the sunken courtyard and the reasons for change in Shanxian County, Henan Province," J. Rural Stud., vol. 47, pp. 630649, 2016.

24. L. Martinelli and A. Matzarakis, "Influence of height/width proportions on the thermal comfort of courtyard typology for Italian climate zones," Sustain. Cities Soc., vol. 29, pp. 97-106, 2017.

25. A. Forouzandeh, "Numerical modeling validation for the microclimate thermal condition of semi-closed courtyard spaces between buildings," Sustain. Cities Soc., vol. 36, pp. 327-345, 2018.

26. S. Sharples and R. Bensalem, "Airflow in courtyard and atrium buildings in the urban environment: A win tunnel study," Sol. Energy, vol. 70, no. 3, pp. 237-244, 2001.

27. I. Rajapaksha, H. Nagai, and M. Okumiya, "A ventilated courtyard as a passive cooling strategy in the warm humid tropics," Renew. Energy, vol. 28, no. 11, pp. 1755-1778, 2003.

28. A. Tablada, B. Blocken, J. Carmeliet, F. De Troyer, and H. Verschure, "Geometry of Building's Courtyards to Favour Natural Ventilation: Comparison Between Wind Tunnel Experiment and Numerical Simulation," in Proceedings of The 2005 World Sustainable Building Conference in Tokyo, 2005, pp. 2184-2191.

29. A. S. Muhaisen, "Shading simulation of the courtyard form in different climatic regions," Build. Environ, vol. 41, no. 12, pp. 1731-1741, 2006.

30. A. S. Dili, M. A. Naseer, and T. Z. Varghese, "Passive environment control system of Kerala vernacular residential architecture for a comfortable indoor environment: A qualitative and quantitative analyses," Energy Build, vol. 42, no. 6, pp. 917-927, 2010. 
31. N. Sadafi, E. Salleh, L. C. Haw, and Z. Jaafar, "Potential thermal impacts of internal courtyard in terrace houses: A case study in tropical climate," J. Appl. Sci, vol. 8 , no. 15 , pp. $2770-2775,2008$.

32. A. Almhafdy, N. Ibrahim, S. S. Ahmad, and J. Yahya, "Courtyard Design Variants and Microclimate Performance," in Procedia - Social and Behavioral Sciences, 2013, vol. 101, pp. 170-180.

33. A. A. Jamaludin, H. Hussein, A. R. Mohd Ariffin, and N. Keumala, "A study on different natural ventilation approaches at a residential college building with the internal courtyard arrangement," Energy Build, vol. 72, pp. 340-352, 2014.

34. T. Kubota, D. H. C. Toe, and D. R. Ossen, "Field investigation of indoor thermal environments in traditional Chinese shophouses with courtyards in Malacca," $J$. Asian Archit. Build. Eng, vol. 13, no. 1, pp. 247-254, 2014.

35. M. A. Zakaria and T. Kubota, "Environmental Design Consideration for Courtyards in Residential Buildings in Hothumid Climates: A Review," Int. J. Built Environ. Sustain, vol. 1, no. 1, pp. 45-51, 2014.

36. A. M. Nugroho, M. H. Ahmad, and D. R. Ossen, "A Preliminary Study of Thermal Comfort in Malaysia's Single Storey Terraced Houses," J. Asian Archit. Build. Eng, vol. 6, no. 1, pp. 175-182, 2007.

37. A. Auliciems and S. V. Szokolay, "PLEA Handbook - Thermal comfort," PLEA Int., 2007. 